\title{
Correction to: A ZVS high step-up converter based on an integrated boost-cuk topology
}

\author{
Jalil Jalili $^{1} \cdot$ Sayyed Mohammad Mehdi Mirtalaei ${ }^{1}\left[\right.$ Mohammad Reza Mohammadi $^{1} \cdot$ Behrooz Majidi $^{1}$
}

Published online: 30 November 2021

(c) Springer-Verlag GmbH Germany, part of Springer Nature 2021

\section{Correction to: Electrical Engineering https:// doi.org/10.1007/s00202-021-01340-3}

In the original publication, the affiliation of authors was incorrectly published, and this has been revised in this correction as follows:

Department of Electrical Engineering, Najafabad Branch, Islamic Azad University, Najafabad, Iran.
The original article has been updated.

Publisher's Note Springer Nature remains neutral with regard to jurisdictional claims in published maps and institutional affiliations.

The original article can be found online at https://doi.org/10.1007/ s00202-021-01340-3.

Sayyed Mohammad Mehdi Mirtalaei mirtalaei.iaun@gmail.com

1 Department of Electrical Engineering, Najafabad Branch, Islamic Azad University, Najafabad, Iran 